\title{
Advantages and Disadvantages of Computer Assisted Instruction in Chemistry Teaching
}

\author{
Yuanyuan Wang \\ Kunming Fire Service Training School \\ f1009541492@qq.com
}

Keywords: Computer assisted instruction; Chemistry teaching; Advantages and disadvantages

\begin{abstract}
The appearance of computer-aided instruction (CAI) shows the improvement of teaching methods and means, as well as the change of teaching idea and teaching content. However, it also has some problems in the optimistic development. To take full advantages of CAI and improve the teaching effect through it, this paper discusses the advantages and disadvantages of CAI in Chemistry teaching and the simple strategy of problem solving.
\end{abstract}

\section{Introduction}

With the computer technology involved in chemistry teaching system, it is obvious that the traditional teaching methods and means fail to meet the needs of modern teaching. Teachers need to obtain the courseware production material, make and evaluate the courseware. Since CIA can give full play to the computer on the text, graphics, animation, video, audio and other media integrated processing capabilities, as well as flexible man-machine communication and other characteristics, the intuitive teaching principles can be reflected and the students' senses demand can be met fully, obtaining a great active classroom atmosphere, enriching the classroom teaching content, stimulating students learning interest and curiosity, and making students more focused, therefore the classroom teaching quality and effectiveness can be significantly improved. Thus, CIA is welcomed by the majority of educators and carried out like a raging fire at all levels of schools in China in recent years.

\section{Concept and Basic Requirements of Chemistry CAI courseware}

Chemistry CAI courseware is the software to disseminate teaching content in accordance with the scheduled Chemistry teaching program or teaching syllabus. To make good use of this new teaching method in Chemistry teaching, partially replacing teachers to teach and train students, the key is to design a good Chemistry courseware.

Tools presently used for Chemistry CAI courseware production include Powerpoint, Authorware and Courseware Master. The basic requirements for good Chemistry CAI courseware are as follows:.

(1)Teaching objectives appropriate, meeting the requirements of the syllabus and the practical needs of teaching.

(2)No scientific error.

(3)Being available to promote the overall development of students, helping students solve the difficult knowledge, beneficial to the student intelligence development and training students ability.

(4)Appropriate text, graphics and language which can clearly and accurately describe the teaching content, while the degree of the content difficulty is appropriate, and the styles of the problem asking and answering are easy to be accepted by students.

(5)Simple and beautiful screen display, suitable and coordinated sound play without prejudice to students,.

\section{The Advantages of CAI Chemistry Teaching}

CAI Chemistry teaching can create teaching scenarios, optimize classroom teaching, and more fully mobilize and initiate students' learning enthusiasm and the spirit of inquiry, which are mainly as follows: 
Increase of Reading Information and Practical Examples of Production and Life. CAI courseware can show fast information with wide range in a short time, displaying a lot of content for the classroom teaching, providing a wealth of reading materials, environment and background relating with teaching content. The form of reading materials is varied, usually integrated with the text, image, voice recording, video and so on. For example, during teaching the nature of nitrogen, the nitrogen of the laboratory system, photochemical smog, car exhaust purification and other extracurricular reading materials, can be supplied additionally, not only to improve students' interest in learning and learning consciousness but also to broaden their horizons.

Since Chemistry knowledge has a wide range of applications in the production and daily life, CAI courseware can move these production scenes from life to the classroom, changing them into the students' knowledge, creating a practical application of Chemistry knowledge of the scene and setting up bridge from Chemistry knowledge to real production and life in the minds of students experiencing the Chemistry value.

Teaching Efficiency Improvement by Concreting Abstract Content. The biggest advantage of multimedia teaching is the use of computer technology to optimize the combination of dynamic video (video), animation, photos (pictures) and sound, and express oral content in real life (abstract content) clearly to students, highlight the focus of teaching activities, resolve those doubts and difficulties in the teaching content to achieve the best teaching results.

Such as the formation of ion bonds and covalent bonds, the electron gain and loss in the redox reaction, the electronic movement of the electrode reaction in the electrolytic cell, etc., using the CAI dynamic simulation can make the microscopic world intuitively and is convenient for students to understand the essence of the reaction. Furthermore, chemical principle can be stimulated vividly and dynamically. For example, in industrial production of sulfuric acid, the reaction mechanism in the reactor at three main stages can be modeled. One is the boiling furnace simulation map, in which the air flows from the bottom of the boiling furnace into the ore from the top down, the furnace reaction like "boiling water", hence it is called "boiling furnace. The second is the reaction process about the purified air in the contacting room. The third presents the process of $98.3 \%$ concentrated sulfuric acid absorbing sulfur dioxide in the absorption tower. Through the above three dynamic simulation scenarios, students can better learn the Chemistry knowledge, combine Chemistry knowledge to the practical application of chemical principles organically, and deepen the acknowledge degree of their knowledge.

Supplement Chemistry Experiments to Improve Experimental Design Capabilities. Chemistry is an experimental-based discipline with experimental teaching as an important part of teaching. Due to the restrictions of objective conditions, many experiments can not be completed in the classroom, such as explosion of $\mathrm{H} 2$ and $\mathrm{F} 2$ in the dark encounter, reactions of metals $\mathrm{Rb}$, Cs with water and colloid electrophoresis and so on. The computer functions of video and simulation break through these difficult experiments, strengthen the teaching of the intuitive, and optimize the teaching effect. Another example is the reaction of sodium with water, which reacts intensively with complex phenomenon hard to observe and changing very quickly, it is difficult for students to observe clearly and overall on site practically. Using CAI to demonstrate the experiment and then simulate it times can not only make students get all the information about the react, but also learn to observe things from different viewpoints, as well as develop good observation habits.

The use of CAI courseware can added some experiments outside textbooks or not required to be demonstrated, such as the wrong operation in the experiment,. With CAI simulation, the results of illegal operations can be shown to students to effectively prevent wrong operation. For example, with $\mathrm{H} 2$ to reduce $\mathrm{CuO}, \mathrm{H} 2$ should first pass before heating, which students often ignore. Using CAI to simulate the opposite

operation and the explosion, students will be impressed with a more profound experience and understanding the importance of standardized operation .

With application of CAI simulation and interactive functions, the limitations of time and space can be overcome. For example, the production of $\mathrm{H} 2$ in laboratory, students are asked to assembly $\mathrm{H} 2$ 
generator device according to the equipment provided by the computer, improving the students' thinking divergence and imagination capability.

As only an auxiliary, which is just right, such as to provide learning materials, demonstrate experiment in class which is failed in laboratory, etc., CAI education can really play a role. If all the teaching contents in teaching process are on the screen, there will exist some phenomenon failing to make good use of CAI , and therefore expose the disadvantages of CAI.

\section{Disadvantages of CAI Chemistry Teaching}

Computer Instead of Blackboard. The entire teaching process is completed by the computer, and the lesson plans and teachers' explaining in the whole process turn out to be computer play, which is the biggest drawbacks of CAI Chemistry teaching. With blackboard for chemistry teaching, the blackboard writing follows strict logical thinking and reasoning process, but CAI courseware is prepared in advance, lack logic and reasoning, and generally designed roughly, and the expression of knowledge is lack of new ideas, ignoring teachers' emotional communication with students and personality quality education of students, which is only against the teaching objectives. Moreover, students will feel tired and bored of learning.

Image Thinking without Abstract Thinking. The computer is characterized by the ability to make the static into the dynamic and the abstract into the image. But using CAI courseware too much and visualization all the problems are not convenient to the cultivation of abstract thinking. Changing all teaching content into the images will decrease the abstract ability of students, such as the teaching of basic chemistry concepts and principles has a strict logic and strong ideological, as well as a high degree of abstraction and generalization, in which a weak abstraction thinking ability is not good for Chemistry learning.

Fabulous but Not Practical Courseware Production. Courseware produced beautifully, gorgeous, and with color too bright often distract the students' attention, interfering their understanding of the Chemistry formula, phenomena and theorem, which is not convenient to discover the nature of the problem. We should pay attention to the connotation of courseware, pay attention to the harmony of the teaching content and structure, simpleness and novelty of the problem solutions, coming to the conclusions originally, correctly and uniformly, not the gorgeous appearance of CAI courseware.

Only Teachers' Teaching without Students Learning. At present, most teachers focus on teaching method when making Chemistry courseware to clarify the problem that the other teaching aids can not explain, rarely using the computer to help students learn. Most teaching designs treat teaching as the main part. In the teaching process, students are the main body,. Therefore, courseware must be conducive to students' participation, prompting the essence of teaching content and the efficient classroom communication.

Demonstration of Experimental Phenomena Without Training Capacity. Experimental phenomenon, such as microstructure, that difficult to be carried out in the classroom, can be simulated through the computer demonstration. Therefore, students may feel the image and interested. But during the demonstration and simulation process of Chemistry CAI, the experimental design of students and operational process are ignored without improvement of the students' imagination and innovative thinking.

\section{Computer Aided Chemistry Teaching Problem Solving Strategy}

Blackboard. Whether the blackboard is necessary or not in the CAI teaching is determined by the characteristics of the subject and the type of the teaching. As for the Chemistry theorem and the formula, blackboard is necessary, while review class does not need blackboard, since teacher can use courseware through complete all the teaching tasks. Therefore, the Chemistry teaching courseware should focus on teaching points and difficulties being enriched and selected to generally control the courseware presentation time about 10 minutes, while teachers' teaching is still the main. It is unnecessary to teach 
everything in one lesson, and one or two teaching points are enough. As for problem not easy to explain, it is feasible to use the unique advantages of courseware to make it clear.

Teaching Content. To achieve the best teaching results, the contents of courseware should be combined with students' cognitive characteristics, take full account of the students' interest in learning, cross and integrate the education, psychology, computer and other related knowledge organically, so that courseware appears in the most needed and most critical places. The contents of most coursewares pay attention to the teacher's "teaching" instead of the students "learning". To solve this problem, teachers can choose intelligent software (such as Qingdao SHIYOU Software), so that teachers consider subjectively and make good courseware. When students in the actual teaching put forward a new problem, the computer can strengthen the students' thinking training by demonstration of the intelligent platform.

Application Time. As a teaching aids to solve a certain teaching point and difficulty, CAI need not to be used throughout the whole classes, a fragment is enough for the needs. Since the teaching is a complete whole composed by the computer, courseware, teachers, students together, to the use of the courseware through the partial or the whole class depends on whether the courseware can complete all the classroom teaching tasks. Chemistry is a discipline that student must personally calculate or operate, the former use of courseware is better.

Application Frequency. First of all, not all of the subjects are suitable for computer courseware production, and there is no need to use courseware in all classes during a semester of teaching. If that happens, the teaching effect will not be ideal due to students' long-term of high degree mental concentration. Secondly, the teachers spend a lot of time and effort to produce courseware, for example, a public class courseware costs at least one month's time, while a normal lesson also costs three or five nights.Hence, the energy and efforts spent on other classes must be discounted. Frankly, the use of CAI courseware should be appropriate, especially for young teachers to understand the basic production principles, and truly play the advantages of CAI. Chemistry experiments should be done in the laboratory instead of the computer demonstration. Computer can calculate and map based on the experimental data obtained to conclude the Chemistry theorem or explain the experiment result, really playing a computer auxiliary role.

\section{References}

[1] Zhong Qiquan, Zhao Zhongjian. Teaching theory. Shanghai: East China Normal University Press, 2003: 131-133.

[2] Fan Hongjun. Inorganic Chemistry. Kunming: Yunnan People's Publishing House, 2010: 216.

[3] Zhu Jiatai, Li Jun.Art of chemistry teaching. Nanning: Guangxi Education Press, 2002: 78-79.

[4] Z. Zeng. Constructivism Study Theory and Multimedia Network English Listening Teaching. English Language Teaching and Research, Vol.28(2007): 64-65

[5] J.P. Chen, X.W Tan.English Teaching in Classroom Assisted by Computer Centered Multimedia. Journal of Wuhan Institute of Science and Technology, Vol 6.(2004): P.68-71

[6] Z.Y. Deng. The Advantages and the Drawbacks of Multimedia Teaching Way of the Computer. Journal of Electrical \& Electronic Education, Vol.2(2006): 98-103

[7] S. Li, X.W. Sun, etc. Research for Radiological Educational Revolution with Multimedia through Network. Medical education, Vol.6(2005): .41-42

[8] Z. Zeng. Constructivism Study Theory and Multimedia Network English Listening Teaching. English Language Teaching and Research, Vol.28(2007): 64-65

[9] C.S. Wan. Development and Thinking of Multimedia CAI in Chinese Higher Medical Education. Journal of Shanxi medical University: Basic Medical Education, Vol.3(2000) : 189-191 
[10]F.Y. Zhuang. Realization of Multimedia Courseware in Clinical Electroencephalography. Medical Education, Vol.1(1997) : 33-35 